\title{
Legal Protection For Users Of Air Cargo Transportation Services (Study At PT. Anugerah Semesta Persada)
}

\section{Rio Peranata Sebayang}

Sumatera University Faculty Of Law. E-mail: riosebayang99@gmail.com

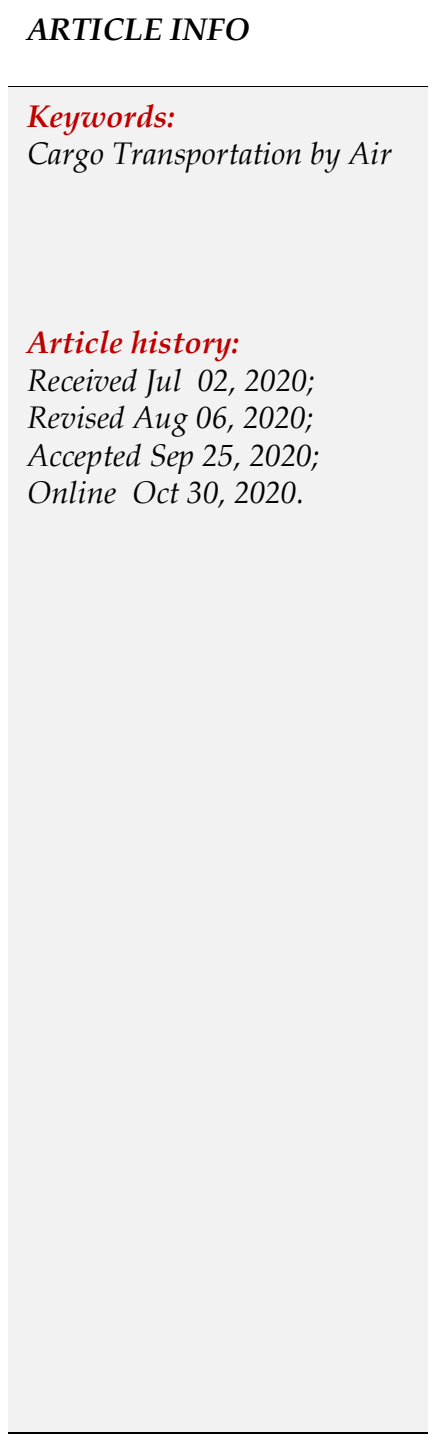

\begin{abstract}
Implementation of the rights and obligations of users of cargo transportation services, PT. Anugerah Semesta Persada (EMPU) and airlines are included in the expedition agreement where the agreement is a reciprocal agreement between the forwarder and the sender, and the forwarder binds himself to find a good carrier for the sender, while the sender binds himself to pay fees. to the forwarder. This expedition agreement is included in the air transportation agreement so that it must comply with the Law of the Republic of Indonesia Number 1 of 2009 concerning Aviation. The method used in this paper is normative research, namely research conducted by examining library materials related to the problem to be studied. Library materials used as sources of research are obtained from books, articles, papers, magazines, and electronic media such as the internet. The case study was conducted at the PT. Anugerah Semesta Persada (EMPU) is a company that operates as an expediter under the leadership of SUHENDRA and REKAN in order to complete the data in completing the research. The conclusion shows that the implementation of the rights and obligations of users of cargo transportation services, PT. Anugerah Semesta Persada $(E M P U)$, and airlines are included in the expedition agreement where the agreement is a reciprocal agreement between the forwarder and the sender, and the forwarder binds himself to find a good carrier for the sender, while the sender binds himself to pay fees. to the forwarder. The aircraft used in this transportation are passenger aircraft. Carriage using checked baggage on passenger aircraft. Baggage must not exceed capacity so as not to endanger flight safety. The responsibility of PT. Anugerah Semesta Persada and airline companies in carrying out cargo transportation by aircraft are lost in whole or in part, when damaged, and late arriving at the destination. This expedition agreement is included in the air transportation agreement so that it must be subject to the Law of the Republic of Indonesia Number 1 of 2009 concerning Aviation. Implementation of legal protection for users of aircraft cargo transportation services at PT. Anugerah Semesta Persada is regulated in the Decree of the Minister of Transportation No. KM 77 of 2011 concerning Responsibilities of Air Transport Carriers.
\end{abstract}

This is an open access article under the CC BY-NC license.

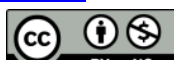

\section{Introduction}

Legal protection is a protection given to legal subjects in the form of legal instruments, both preventive and repressive, both written and unwritten. justice, order, certainty, benefit, and peace. A system of legal protection for consumers of air transportation services is a system consisting of laws and regulations and procedures that regulate all aspects, both directly and indirectly, regarding the interests of consumers of air transportation services. 
Air transportation law is the most recently developed mode of transportation law, namely sea, land, and rail. At first, airplanes were only used to carry passengers, so it is not surprising that the growth of the law regarding the liability of air carriers to passengers is greater than the growth of carriers' responsibilities to cargo. In its development, cargo transportation began to show an important role.

Transportation by using the airplane mode is more profitable than using the mode of transportation on the road by using a car, train, or sea by using a ship because air transportation by using an airplane is faster, more comfortable, can reach more destinations without obstacles or congestion such as travel by using the mode of transportation on the road. Air transportation using airplanes is affordable for many people.

The need for media that can quickly relieve and streamline human activities in their daily lives makes transportation facilities increasingly important. This need creates demands from the community for an ideal means of transportation. Ideal both in terms of quality, quantity and protection offered for their safety as users of transportation services. The rapid spread of land transportation services is accompanied by increasing technology and then followed by sea transportation services that offer each other's convenience to air transportation services which are increasingly in demand by the public. Of the three transportation services offered above, air transportation services are indeed the most recently developed and are now a mainstay for several business actors engaged in transportation services.

Air transportation services offer different qualities from the other two types of transportation, namely land transportation and sea transportation. The effectiveness of the time and services provided makes air transportation services look more bona fide than others. In direct proportion to the quality offered, the tariffs and legal protection provided to users of air transportation services are also different, so that it becomes a necessity for laws to cover and regulate air transportation. Considering that air transportation is a matter of transportation between countries, international forums have emerged that discuss the rules regarding this matter. Starting from the Paris convention in 1919 to the Warsaw convention in 1929, it was born from the international forum and became a reference for transportation law in several countries, including Indonesia.

Prior to the birth of the conventions on air transportation, the carrier's responsibility initially applied rules analogously to other legal fields, especially from the field of civil law, especially the field of transportation law. However, this does not bring satisfaction to consumers so a separate law is formed to regulate it.

The development of users of cargo transportation services by aircraft continues to increase along with its rapid development. For domestic cargo transportation, from the available capacity it utilized 507,894,000 tons $\mathrm{km}$ for $1988 / 1989$ to $668,492.000$ tons $\mathrm{km}$ in 1992/1993 and for foreign cargo transportation utilized 1,224,623,000 tons $\mathrm{km}$ to $1,555,034,000$ tons $\mathrm{km}$ in $1992 / 1993$, while up to $1996 / 1997$ for the domestic market it was $984,874,000$ tons $\mathrm{km}$, and for foreign countries it was 1,956,203,000 tons $\mathrm{km}$.

Aircraft engineers in addition to creating innovations in serving the cargo market, they also make modifications to existing aircraft. However, it is not always possible to carry out transportation properly, because it is impossible to rule out the occurrence of things that cause losses for the users of cargo transportation services through air transportation.

The responsibility for air transportation service users is based on the agreement between the carrier and the passenger, so that if something happens that causes harm to the air transportation service user, the carrier can be held accountable. During transportation, the control of the aircraft and its contents is in the hands of the carrier. Therefore, it has become 
clear that all losses arising from damage, loss, and/or destruction of cargo are the responsibility of the carrier, except for cargoes in the event of:

a. The condition, quality or damage of the cargo itself;

b. Errors in packaging made by the carrier, its workers, or its agents;

c. War;

d. An act of control with respect to the entry, exit and transit of cargo.

The carriage agreement, whether closing it or executing it, is mostly left to another person who is an expert in the relevant field. For example, when closing a carriage agreement or ship charter agreement, the former is handed over to the expediter, while the second is to a ship broker (cargadoor). The convooiloper or agent-duane (this function is now performed by EMKL) performs in- and out-clearing. The load controller (stuwadoor) or compact interpreter takes care of loading and unloading. These functions are sometimes combined in one or two companies, for example, there is an EMKL company that functions as an expediter, ship broker, and agent-duane or convooiloper, while another company functions as a loading (stuwadoor) and unloading cargo.

The forwarder is found in the agreement for the carriage of goods, in English it is called cargo forwarder. The forwarder is classified as a legal subject of transportation because it has a very close relationship with the sender or carrier or recipient of the goods. The forwarder functions as an intermediary in the carriage agreement acting on behalf of the shipper. If an intermediary is willing to find a good carrier .

\section{Method}

The method used to research and analyze in writing this thesis is a descriptive analysis method with a sociological juridical approach. The use of this method is to see a problem that exists in people's lives by taking the place or research location at PT. Anugerah Semesta Persada is a company engaged in the transportation of goods by air to be used as an ingredient in the writing of this thesis.

a. Literature study (library research)

That is by searching for, collecting reading materials, articles and laws and regulations related to this paper to be used as a basis for thinking for the sake of the scientificity of this thesis.

b. Field research (Field research)

That is a study conducted to the company PT. Indah Sakti which is engaged in the transportation of goods via land transportation to study the documents related to the material of this thesis for the sake of the scientific of this thesis as well.

With these two research and data collection techniques, the author then processes the existing materials and data and then presents it in accordance with the systematic discussion of this thesis and based on this the author provides conclusions and suggestions that may be useful for legal science, especially Civil Law.

\section{Analysis And Results}

3.1 Rights and Obligations of PT. Anugerah Semesta Persada as a Cargo Transportation Service Provider and Implementation of its Cooperation with Airline Companies

All countries in the world that always need cooperation with other countries to be able to meet their needs. So this gives rise to a reason for the occurrence of trade relations with other countries. At present, International Trade Relations are the most efficient priority scale for a country to enable the development of new technological innovations, thereby expanding production, consumption and service options. In other words, goods and services are objects of 
trade. So it is common in the world of trade that the principle of balance between demand and supply will arise based on an agreement on what is the object of trade and the existence of buying and selling activities.

The sender is obliged to fill out the air cargo form for the benefit of the carrier and himself. In that air bill. The sender must provide complete information about the goods to be sent. Regarding the truth of these statements, the sender is responsible, meaning that the sender is responsible for all losses suffered by the carrier or other parties as a result of his notification and his/her information which is inaccurate, wrong or incomplete (article $12 \mathrm{OPU}$ ).

The consignor is also obliged to accompany the bill of lading with the necessary documents on the requirements of the goods to the consignee, to comply with the requirements of customs, local and police taxes. Regarding the completeness of these documents, the sender is responsible, which means that if there is a loss due to the absence, incompleteness or inaccuracy of the documents, which is suffered by the carrier, the sender is responsible for the loss to the air carrier. Regarding the truth of the statements, whether the documents are complete or not, the carrier is not obliged to check them (Article 13 of the OPU).

It is impossible for the carrier to carry out the order of the sender, then he must notify the sender who gave the order. But if the carrier has been able to carry out the sender's order, he must ask for the return of the air cargo that has been given to him. Otherwise, he is responsible for the other party who legally owns the bill of lading, without prejudice to the right of the carrier to demand reimbursement from the sender. The sender's right to control the goods is lost when the recipient begins to exercise his rights, namely when the goods have arrived at the destination airport, the recipient demands the delivery of the air cargo letter and the goods by:

a. Pay all costs that are their obligations.

b. Fulfill the provisions as stated in the air cargo letter. It is at this point that the sender's right to control the goods disappears.

The carrier is obliged to notify the consignee when the goods have arrived at the destination airport, unless there is an agreement otherwise.

The recipient has the right to demand the delivery of the air cargo letter with his goods if he has fulfilled his obligations by paying the transportation fee and fulfilling all the provisions stated in the air cargo letter in the event that:
a. Recipient didn't come
b. The recipient refuses to accept the goods
c. The recipient refuses to pay what he owes
d. When the items are confiscated

The carrier is obliged to store the goods in a good place at the responsibility of the person who is entitled to it and the carrier is obliged to notify the sender, in the event of a confiscation, must also notify the recipient, as soon as possible by telegram or telephone at the expense of the rightful person, about the storage and the reasons for it. (Article 17 of the OPU).

The carrier is obliged to sell the goods in whole or in part in the most appropriate way and it is immediately notified to the sender if the goods stored are perishable, and the sender after 12 hours has elapsed since he was notified of the storage does not take care of the goods. The right to sell the goods can also be given to a person who is authorized by the Head of the local District Court, provided that the proceeds of the sale are used to pay money. Transportation and storage costs, while the rest is kept by the competent Head of the District Court (article 18 OPU).

The provisions of Article 17 of the OPU state that if the cargo is confiscated, the carrier is obliged to store the goods in a good place. If the carrier violates this provision, namely handing 
over the goods to the recipient, then he is personally responsible for the losses incurred by the person who confiscates. In this case, the recipient is considered to be aware of the confiscation of the goods, unless there is evidence to the contrary. And if the confiscation is not a revindication confiscation, then the claim can be charged to the goods in question (Article 19 of the OPU).

The carrier loses the right to get the rest of the transportation money from the sender if the carrier has delivered the goods to the recipient and the transportation fee has not been paid in full. In this case, the carrier's claim to the recipient expires after one year has passed. This time period starts from the start of the end of the trip (article 20 paragraph (2) of the OPU).

The recipient who has received the baggage or goods without protest, is considered that the goods or baggage have been received in good condition. In the event of damage, the recipient must file a protest with the carrier as soon as the damage is known and no later than 3 days for baggage and 7 days for cargo goods, starting from the receipt of the baggage or goods concerned. In case of delay, the protest must be filed within 14 days after the day the goods or baggage were in his possession (article 35 OPU).

A. Responsibilities of PT. Anugerah Semesta Persada and the Airline Company in the Implementation of Cargo Transportation by Airplane

Articles 24 and 25 of the Air Carriage Ordinance stipulate that the carrier is responsible for losses as a result of the injury or death of a passenger and as a result of the destruction, loss or damage to baggage or goods, without explicitly establishing the basis of liability for this matter. We see something similar in the Warsaw Convention. On the other hand, the trade law which regulates sea transportation expressly stipulates in article 468 that "a carriage agreement requires the carrier to maintain the safety of the goods he must transport, from the time it is received until the time the goods are handed over", while article 522 stipulates that "the agreement carrier to maintain the safety of the passenger, from the moment the passenger enters the ship until he leaves the ship.

The Rome Convention of 1952 which regulates liability to third parties on land, is somewhat more assertive, because chapter I of this convention is entitled "Principles of Liability", while in the Air Carriage Ordinance the issue of liability is regulated in chapter II entitled "Carrier Responsibilities. " and in the Warsaw Convention in chapter III on "Liability of Carrier", without mentioning the basis or principles of liability.

There are two liability systems in domestic air transport, one system for passengers, checked baggage, and goods and one system for hand baggage. Based on this system, the carrier is considered always responsible for the loss caused by the injured or dead passenger, due to checked baggage or lost, destroyed or damaged goods. The aggrieved party does not have to prove the fault or negligence of the carrier, what must be proven is only the amount of the loss suffered.

\section{B. Legal Protection for Aircraft Cargo Service Users (Study at PT. Anugerah Semesta Persada)}

The party who is legally responsible is called the carrier. Because in general the carrier is a legal entity, those who carry out the transportation agreement are the employees, agents, and other parties who carry out the transportation, either based on a work agreement or other agreements. Apart from that, as we have seen above, in certain transportation agreements such as mixed and charter transportation, there may be a question of who is called the carrier and who is called responsible, while in international air transportation the responsibility for losses incurred by third parties is aircraft operator (entrepreneur, exploiter) or owner. 
Judging from the provisions of Law Number 8 of 1999 concerning consumer protection, in article 1 number 2 it is stated that consumers are every person who uses goods and/or services available in the community, both for the benefit of themselves, their families, other people, and other living beings. and not for trading, it is further explained in article 1 point 2 that in the economic literature the terms end consumers and intermediate consumers are known. End consumers are end users or beneficiaries of a product, while intermediate consumers are consumers who use a product as part of the production process of another product. Normatively, through Law Number 8 of 1999 concerning Consumer Protection, 9 consumer rights are stipulated, which include:

1) The right to comfort, security, and safety in consuming goods and/or services;

2) The right to choose goods and/or services and to obtain such goods and/or services in accordance with the exchange rate and the promised conditions and guarantees;

3) The right to correct, clear and honest information regarding the conditions and guarantees of goods and/or services;

4) The right to have their opinions and complaints heard on the goods and/or services used;

5) The right to get advocacy, protection and efforts to resolve consumer protection disputes properly;

6) The right to obtain consumer guidance and education;

7) The right to be treated and served correctly and honestly and not discriminatory;

8) The right to receive compensation, compensation and/or replacement, if the goods and/or services received are not in accordance with the agreement or not as they should be;

9) Rights regulated in the provisions of other laws and regulations. ${ }^{54}$

The provisions of Law Number 8 of 1999 must be fulfilled by the airlines or airlines as carriers and PT. Anugerah Semesta Persada as a provider of cargo transportation services. Carriers and agents must fulfill their obligations, namely fulfilling consumer rights as written in article 1 number 2 of Law number 8 of 1999 concerning consumer protection so that the sender / shiper gets protection and his rights as users of cargo transportation services or more accurately said to be consumers.

In the case of filing a claim for compensation, what is important to be noticed by the claimant is the time period for the protest, i.e. known damage and no later than three days and seven days for goods, starting from the receipt of baggage or goods and for delays not later than fourteen days after baggage and goods are placed in his control.

Provisions regarding the responsibility of the carrier are regulated in the Decree of the Minister of Transportation Number. KM 77 of 2011 concerning Responsibilities of Air Transport Carriers with the background:

1) Provide understanding to providers and users of air transportation services about the meaning of a "ticket", "air cargo letter" and "claim tag"

2) The responsibility of the Government as a facilitator to balance rights and obligations between providers and users of air transportation services and third parties;

3) Provide legal certainty between service providers and air transportation service users in conducting legal engagements for air transportation services and third parties; 55

Air transportation disputes can be settled in two ways, namely through the District Court in the Territory of the Republic of Indonesia and through arbitration or other alternative dispute resolutions in accordance with the provisions of the legislation.

1) Through Court

In Indonesian jurisprudence, there are only three cases regarding aviation, namely the case of Sarah Oswald-Vermaak versus PN Garuda, for the Dakota accident at Mount Burangrang in 1960, and at the cassation level it was decided by the Supreme Court in 1967 (responsibility to passengers). the second is the case of the Beechraft aircraft belonging to LPPU in 1975 (responsibility for losses to third parties on the ground) and the third is the 
case of The Central Bank and Trust Company against PT. Mandala Airlines and PT. Bank Windu Kencana, 1972 (regarding the sale and purchase of airplanes). Relevant to the issue of liability are the first and second issues, and should be investigated carefully whether they can provide clues about the status of civil air law in Indonesia.

2) Out of court

In general, compensation settlements are settled out of court. For claims of loss on baggage and any items Airline companies have their own procedures, ranging from reporting, investigation, decision making regarding the amount of compensation, and payment.

In the case of filing a claim for compensation, what is important to be noticed by the claimant is the time period for the protest, i.e. known damage and no later than three days and seven days for goods, starting from the receipt of baggage or goods and for delays not later than fourteen days after baggage and goods are placed in his control.

The protest must be in writing. It should also be noted that to sue must be within two years after the aircraft arrives at the destination or the day the aircraft is supposed to arrive. For the carrier, what is important to note is that in the payment of compensation, the receiving party must be entitled, and must sign a statement, known as the "final release", which contains the release for the carrier from all claims from any party regarding the loss.

A peaceful settlement is ideal, however, as with a settlement before the court, it must also meet the requirements of being fast, easy, cheap and satisfying. It is unfortunate that although in general compensation issues are resolved out of court, in general the settlement is not fast and satisfactory, especially for the settlement of compensation for passengers, which except in one case, in Indonesia everything was done outside the Court.

\section{Conclusion}

Implementation of the rights and obligations of users of cargo transportation services, PT. Anugerah Semesta Persada (EMPU), and airlines are included in the expedition agreement where the agreement is a reciprocal agreement between the forwarder and the sender, and the forwarder binds himself to find a good carrier for the sender, while the sender binds himself to pay fees. to the forwarder. This expedition agreement is included in the air transportation agreement so that it must comply with the Law of the Republic of Indonesia Number 1 of 2009 concerning Aviation.

Responsibilities of PT. Anugerah Semesta Persada and airlines in carrying out cargo transportation by aircraft are as follows: (1) Lost in whole or in part, the price of goods of the same kind and the same nature at the place of destination, at the time or goods or baggage should be delivered, is reduced by the amount of money which, because it is not there, does not need to be paid, namely regarding transportation fees and other costs. (3) If damaged, the price of the goods is calculated as above, reduced by the price of the damaged goods, and the remainder is also reduced by the amount of money, which because of the damage does not need to be paid, namely regarding transportation fees and other costs. (4) Late arrival at the destination, this is not only about cargo and baggage, but also about passengers, unless there is another agreement.

Implementation of legal protection for users of aircraft cargo transportation services at PT. Anugerah Semesta Persada is regulated in the Decree of the Minister of Transportation No. KM 77 of 2011 concerning Responsibilities of Air Transport Carriers whose purpose is to: (1) Provide understanding to providers and users of air transportation services about the meaning of a "ticket", "air cargo letter" and "claim tag", (2) The responsibility of the Government as a facilitator to balance rights and obligations between providers and users of air transportation services and third parties; (3) Provide legal certainty between service providers and air 
transportation service users in conducting legal engagements for air transportation services and third parties

\section{References}

Martono, K.., Air Transport Law Based on the Law of the Republic of Indonesia No. 1 of 2009, PT. Raja Grafindo Persada, Jakarta, 2011.

Muhammad, Abdul Kadir, Commercial Transport Law, Citra Aditya Bakti, Bandung, 2008.

Purba, Hasim, Aviation Law and Aircraft Manufacturers' Responsibilities, Pustaka Bangsa Press,. Medan, 2010.

Purwosudjipto, HMN, Basic Understanding of Indonesian Commercial Law, Djambatan, Jakarta, 2003.

Badrulzaman, Mariam Darus. Compilation of Engagement Law, Citra Aditya Bakti, Bandung, 2001.

Suherman,, E., Various Problems of Aerospace Law, CV. MandarinProceed, Jakarta 2000.

Suriaatmadja, Toto T., Legal Aspects in National Air Transport, Bandung, CV. Mandar Maju, 2006. , Air Cargo Transportation, PT. Bni Quraish library, Bandung, 2005.

, Air Cargo Transportation: Carrier Responsibilities in National and International Air Law Dimensions, Bani Quraisy Library, Bandung, 2005.

,Transportation of hazardous materials and/or goods by aircraft based on UURI no. 1 of 2009.

CV. Mandar Maju, Bandung, 2000.

Yustisia Library Team, Aviation Services Security and Safety Standards, Yustisia Library, Jakarta, 2007.

Uli, Sinta, Transportation A Legal Review of Multimodal Transport Sea, Air, and Air Transport. USU Press, Medan, 2006.

Widjaja, Gunawan, Ahmad Yani, International Business Transactions (Export-Import and Buy-back), Raja Grafindo Persada, Jakarta, 2003.

Decree of the Minister of Transportation No. KM 77 of 2011 ; Code of Civil law; Commercial Code;

Government Regulation Number 44 of 1995 concerning Air Transportation; Law Number 15 of 1992 concerning Aviation;

Law Number 1 Year 2009 concerning Aviation;

http://akubukahumanpurba.blogspot.com/2010/07/perlindungan-law-bagi- service-user.html

http://fauzisulton.blogspot.com/2010/02/task-tangan-rahmadi-susilo- 224107157.html

http://mell-benu.blogspot.com/2012/04/buku-ajar- Hukum pengangkutan.html

http://retindotrans.blogspot.com/p/freight-forwarding.html

http://mursyidreza.blogspot.com/2013/06/ Hukum-angkutan-kapal-terbang-di.html

http://bayuyudhaprasetya.wordpress.com/category/ Hukum/ 